\title{
Mehanizmi kontrole i usmjeravanja likovne produkcije: ULUH u kontekstu socrealizma
}

Šeparović, Ana

Source / Izvornik: Institucije povijesti umjetnosti : zbornik 4. kongresa hrvatskih povjesničara umjetnosti, 2019, 277 - 281

Conference paper / Rad u zborniku

Publication status / Verzija rada: Published version / Objavljena verzija rada (izdavačev PDF)

https://doi.org/10.31664/z4khpu.36

Permanent link / Trajna poveznica: https://urn.nsk.hr/urn:nbn:hr:254:435660

Rights / Prava: Attribution 4.0 International/Imenovanje 4.0 međunarodna

Download date / Datum preuzimanja: 2023-04-26

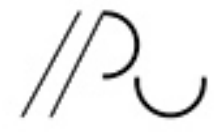

INSIITUTR ZA POVIJEST UMJETNOST
Repository / Repozitorij:

PODEST - Institute of Art History Repository

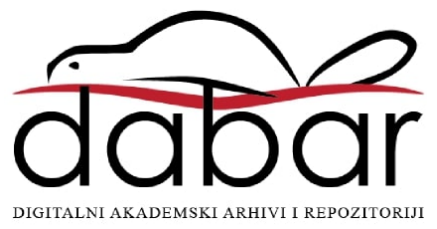


Mehanizmi kontrole i

\section{usmjeravanja likovne produkcije: ULUH u kontekstu socrealizma}

Implementacija socijalizma u zemlje Istočnoga bloka nakon Drugoga svjetskog rata na polju likovne umjetnosti podrazumijevala je ne samo razradu i primjenu sasvim novih formalnih i estetskih obilježja likovne produkcije oslonjene na doktrinu socrealizma ${ }^{1}$ nego i "specifičan oblik totalitarne organizacije svijeta umjetnosti” („ždanovizam”), ${ }^{2}$ sve po uzoru na Sovjetski Savez. U Jugoslaviji se to zbiva najranije od svih socijalističkih zemalja, već I945. godine, ${ }^{3}$ a ključnu ulogu u toj provedbi i primjeni tih načela na područje umjetnosti odigralo je Udruženje likovnih umjetnika Hrvatske (dalje: ULUH) kao „monopolističko nacionalno udruženje umjetnika oblikovano po uzoru na sindikat". ${ }^{4}$ Prema dokumentaciji koja se čuva u Hrvatskome državnom arhivu djelovanje ULUH-a ugrubo bi se moglo podijeliti na tri sfere. Prvo, stručno polje djelovanja Udruženja obuhvaća brigu o likovnom djelovanju, organizaciju godišnjih revijalnih izložbi kao središnjih nacionalnih likovnih priredbi, nabavu stručne literature i organiziranje večernjeg slikanja akta, dok kroz drugu, nazovimo ju ekonomskom sferom djelovanja, Udruženje vodi brigu o umjetničkim atelijerima, nabavi slikarskoga i kiparskoga materijala i prodaji slika (što uskoro preuzima zadruga Likum) te pomaže potrebitim članovima. U ovome radu pozornost će se posvetiti trećoj, idejno-političkoj sferi djelovanja, koja predstavlja kanal kroz koji je država, odnosno Komunistička partija (dalje: KP) kao centar moći, nametala kanon socrealizma na područje likovne umjetnosti. To polje djelovanja ULUH-a trebalo je odigrati važnu društveno-političku ulogu i pridonijeti stvaranju „totalitarnog mentaliteta" odnosno kolektivnog zanosa. ${ }^{5}$

Unutar Centralnog komiteta Komunističke partije (dalje: CKKP) kao vladajuće strukture, djelovao je Agitprop (Odjeljenje za agitaciju i propagandu na čijem čelu je bio Milovan Đilas) kao vrhovno izvršno tijelo za širenje socijalističke ideologije odnosno tzv. partijske linije na sva područja kulturnog i intelektualnog stvaralaštva. ${ }^{6}$ Takva centralizirana struktura omogućila

\section{Ana Šeparović}

Leksikografski zavod Miroslav Krleža anaseparovic@gmail.com

https://orcid.org/oooo-ooo2-I708-8358
I Dosad je u hrvatskoj povijesti umjetnosti umjetnička produkcija socrealizma općenito uglavnom diskvalificirana kao neumjetnost, slabost, oportunizam ili čak kič, a razdoblje između I945. i I95o. u Jugoslaviji jednostavno se zaobilazilo kao moment koji nije bilo poticajan za autentično umjetničko stvaralaštvo. Takvo vrednovanje između ostaloga posljedica je visokomodernističkog razumijevanja umjetnosti kao a priori slobodnog i autonomnog individualnog izraza. Tek u recentnim istraživanjima doktrina socrealizma razmatra se kao sastavni dio međunarodne kulture moderniteta. Doktrina socrealizma i njezine manifestacije $u$ kulturi i umjetnosti $u$ Hrvatskoj predstavljeni su na izložbama u Zagrebu (Hrvatska likouna umjetnost I945.- I955.: Tendenciozni realizam, I974. i Refleksije vremena I945.- I955., 2012.) i Beogradu (kao dio jugoslavenskog socrealizma na izložbi Nadrealizam, postnadrealizam, socijalna umetnost, umetnost NOR-a, socijalistički realizam, I969.). Isti fenomeni razmatrani su u sljedećim člancima i monografijama: BOŽIDAR GAGRO, Nadrealizam, socijalna umjetnost I929-I95o, u: Život umjetnosti, Io (I969.), I49-I67; TONKO MAROEVIĆ, Od stvaralaštva u slobodi do slobode stvaralaštva, u: Radovi Instituta za povijest umjetnosti, 9 (I985.), 9I-92; SUZANA LEČEK, Likovna umjetnost u društvenom životu Hrvatske I945-1947, u: Časopis za suvremenu povijest, I/2 (I990.), I3I-I56; SONJA BRISKI UZELAC, Ikonički znak socijalističkog realizma, u: Knjižeuna smotra, 3/4 (I996.), 55-62; TONKO MAROEVIĆ, Ideja socrealizma u kritičkoj praksi Grge Gamulina. Nekoliko primjera iz vrućih, militantnih godina, I945.- I952., u: Desničini susreti 20og, Intelektualci $i$ vlast I945-I954., (ur.) Drago Roksandić, Magdalena Najbar-Agičić, Ivana Cvijović Javorina, Zagreb, 20II., 28-42; GRGO GAMULIN, Hrvatsko slikarstvo XX. stoljeća, sv. 2, Zagreb, I988., 445-462 (poglavlje „Programirana umjetnost”); JASNA GALJER, Likovna kritika u Hrvatskoj I868- I95I, Zagreb, 2000., 296- 335 (poglavlje „Likovna kritika u znaku totalitarizma”); LJILJANA KOLEŠNIK, Između Istoka i Zapada, Hrvatska umjetnost i likovna kritika 5o-ih godina, Zagreb, 2006. 27-54 (poglavlje „Socijalistički realizam”); LEONIDA KOVAČ, Tübingenska kutija, Zagreb, 20I3., 7-57 (poglavlje „Jesmo li još uvijek moderni”); SANDRA KRIŽIĆ ROBAN, Hrvatsko slikarstvo od I945. do danas, Zagreb, 20I3., I7-32 (poglavlje „Pokušaj organiziranja sustava i usporedne egzistencije 'izvan struje"'); ANA ŠEPAROVIĆ, Croatian Painting and Art Criticism in the Period of Socialist Realism (I945-I950): Theory vs. Practice, $\mathrm{u}$ : Art and Politics in the Modern Period, (ur.) Dragan Damjanović, Lovorka Magaš Bilandžić, Željka Miklošević, Jeremy F. Walton, Zagreb, 2ог9., $27 \mathrm{I}-28 \mathrm{o}$.

2 LJILJANA KOLEŠNIK (bilj. I), 29.

3 Doktrina socrealizma u Jugoslaviji bila je među najranijima koje su kao službene uspostavljene u državama Istočnoga bloka. Primjerice u Poljskoj, Rumunjskoj, Bugarskoj i Mađarskoj ona se prihvaća I949., a u Čehoslovačkoj i Istočnoj Njemačkoj tek I95I. 
je da se ideologija jednoliko i nepromijenjeno prenese u sve sfere javnoga djelovanja (kultura, znanost, tisak, školstvo, obrazovanje), kao i gotovo potpunu političku kontrolu umjetničke produkcije. Jedna od komisija Agitpropa bila je i kulturno-umjetnička, koju je vodio Marin Franičević, unutar koje je djelovao i likovni sektor, koji je na čelu s Franjom Mrazom bio zadužen za praćenje i kontrolu kompletnoga likovnog života (likovne kritike, medija, sustava nagrada), a samim time i rada ULUH-a.

ULUH je na ideološkom polju djelovao uglavnom posredovanjem svojeg sektora za idejno-politički rad (teoretsko-predavački sektor) u skladu s ciljem Udruženja, prema kojem je potrebno „narodu dati visoko idejna umjetnička djela, koja će biti odraz i poticaj naporima naroda u izgradnji socijalizma". ${ }^{7}$ Osnovano je i povremeno tijelo-sud časti-koji „rješava slučajeve o ogriješenju proti države". Već na skupštini ULUH-a u srpnju I945. na temelju odluka suda časti kažnjeni su neki umjetnici za sudjelovanje u kulturnome životu NDH. ${ }^{8}$ Udruženje organizira diskusije unutar ULUH-a o funkciji umjetnosti, formiraju se kružoci za ideološko i političko uzdizanje članstva, organiziraju se sastanci s diskusijama i kritičkim debatama o političkim i društvenim pojavama itd. ${ }^{9}$

Nema sumnje da se umjetnost, dakle, u to rano poslijeratno doba shvaća kao sredstvo širenja nove ideologije te da stoga treba postati razumljivom svim slojevima društva, po uzoru na sovjetsku socrealističku teoriju koja kao glavnog neprijatelja takve razumljivosti vidi upravo modernizam. Od umjetnika se očekivalo da vizualizira ključne ideje ideološkog diskursa i prevede ih u jezik umjetnosti, ${ }^{10}$ i to prikazujući neposrednu socijalističku stvarnost, osobito teme iz obnove i izgradnje zemlje te partizanske borbe. Od poželjnih stilskih obilježja tražio se realistički pristup i romantičarski zanos; taj tzv. realizam bio je jedini prihvatljivi oblikovni princip, a trebao se manifestirati u poštivanju trodimenzionalnosti forme, jasnoći pri prikazivanju lica i zadržavanju lokalnih osobina kolorita. Putem tih izražajnih sredstava narodu su se trebale predstaviti i približiti politički prihvatljive ideje, poput optimizma i kolektivizma, želje za radom, bratstva i jedinstva i slično.

Osnovne su kategorije socrealističkoga kritičkog instrumentarija tema, sadržaj i forma. Od teme zahtijevalo se prikazivanje suvremene socijalističke stvarnosti, od forme tzv. realistički pristup s herojskim prizvukom, ${ }^{11}$ a od sadržaja idejnost i partijnost. Dok su tema i forma obilježja slike, sadržaj zapravo predstavlja umjetnika: kroz kategoriju sadržaja (odnosno idejnosti i partijnosti) procjenjuje se koliko je umjetnik napredan, odnosno ideološki ispravno usmjeren i angažiran - ta kategorija mjeri podobnost odnosno ideološku lojalnost sama autora vidljivu u umjetničkome djelu ${ }^{12}-i$ to je upravo onaj segment osobnosti umjetnika na koji ULUH nastoji utjecati svojim idejno-političkim sektorom.

Zanimljivo je razmotriti i specifičnu retoriku unutar Društva, s ključnim pojmovima i sintagmama poput „kolektiva”, „kritike i samokritike” te „subjektivnog odraza objektivne stvarnosti”. Društvo u izvještajima sa skupština i plenuma, a čak i članovi
Prema: LJILJANA KOLEŠNIK (bilj. I), 30; PIOTR PIOTROwSKI, Avangarda u sjeni Jalte. Umjetnost Srednjoistočne Europe u razdoblju I945.--I989., (prev.) Barbara Kryżan-Stanojević, Zagreb, 20II., 34-5I (poglavlje „Nadrealistički interregnum ı945.-- I948.”).

4 LJILJANA KOLEŠNIK (bilj. I), 29

5 Prema Borisu Groysu, partijsko vodstvo („dizajneri nesvjesnog”) stvorilo je socrealističku kulturu i umjetnost kako bi utjecalo na kolektivno nesvjesno, odnosno automatiziralo svijest pojedinca i oblikovalo ga po željenom kalupu kontroliranjem njegove okoline, njegove baze, njegova nesvjesnog. Na tome tragu Sonja Briski Uzelac ističe kako političke elite ne djeluju na umjetnost samo kroz pritisak i cenzuru, već i kroz stvaranje ,totalitarnog mentaliteta", odnosno neke vrste kolektivnog transa. Takva se tumačenja nadovezuju na teorije totalitarnih režima; Hannah Arendt, primjerice, ističe sposobnost totalitarnih režima da „zaraze” mase „specifično totalitarnim virusom”, odnosno „totalitarnim mentalitetom". BORIS GROYS, The Total Art of Stalinism, (prev.) Charles Rougle, New Jersey, I992. [orig. izd. I988.], 44; SONJA BRISKI UZELAC (bilj. I), 57; HANNAH ARENDT, Izvori totalitarizma, (prev.) Mirjana Paić Jurinić, Zagreb, 20I5., 300.

6 Više o Agitpropu u: LJUBODRAG Dimić, Agitprop kultura. Agitpropovska faza kulturne politike u Srbiji I945-I952., Beograd, I988.; TATJANA ŠARIĆ, Djelovanje Agitpropa prema književnom radu i izdavaštvu u NRH, I945.-I952., u: Radovi Zavoda za hrvatsku povijest, I (2OIO.), 387-424; TATJANA ŠARIĆ, Agitprop i Matica hrvatska, u: Enciklopedija Matice hruatske, (ur.) Igor Zidić, Zagreb, 20I5., 39-46.

7 Odgovor Saveznom udruženju likovnih umjetnika (dalje: SLUJ) bez nadnevka, Hrvatski državni arhiv (dalje HDA), fond HDLU I979-2, kut. 25.

8 „Na prvoj skupštini Udruženja likovnih umjetnika Hrvatske održanoj I945., Časni je sud zbog raznih oblika suradnje s bivšim režimom kaznio niz umjetnika. Tako je, primjerice, Robert Auer trajno isključen iz ULUH-a zbog suradnje $u$ izdavanju grafičke mape o tzv. izopačenoj umjetnosti, Vladimir Kirin isključen je privremeno, jer je bio na čelu Odjela za umjetnost u Vladi i dizajnirao novac za NDH, Ljubo Babić udaljen je iz djelovanja u javnosti na šest mjeseci (u obrazloženju su kao razlozi isključenja navedeni sljedeći razlozi: “četiri knjige o umjetnosti na ustaškom pravopisu, štampao članke, izradio ustaške ambleme i novčanice, izvodio crtačke radove za njemačko-hrvatsku izložbu u Zagrebu i držao predavanja', a kao olakotna okolnost da je 'zdušno pomagao NOB od I942'), a čitav niz umjetnika javno je ukoren u tiskovinama.” JASNA GALJER (bilj. I), 3I5

9 Zaključci glavne godišnje skupštine, I4. ožujka. I948., HDA, fond HDLU I979-2, kut. 25.

Io Zadaća je bila umjetnika da „vizualiziraju ključne ideje, slikovno 'prevode' kategorije ideološkog diskursa u jezik umjetnosti kako bi se opće pojavilo u pojedinačnom, posebnom, individualnom, napokon u osjetilnom, 'živom ljudskom obliku”'. soNJA BRISKI UZELAC (bilj. I), $5^{8}$.

II Sonja Briski Uzelac istaknula je kako je dio problema terminološke prirode. Pod pojmom „realizam” službena je kritika zapravo podrazumijevala eklektičnu mješavinu stilova: „od 'revolucionarnog duha' devetnaestostoljetnog naturalizma do akademskog naturalizma koji se gubi u populističkom kiču; od realističko-kritičkog viđenja svijeta do verističke sitničavosti; od simbolističke metafore do anegdote; od širine neoklasicizma do karikaturalne megalomanije; od courbetovsko-impresionističke geste $u$ 
društva, kako pokazuju stenografski zapisnici, u govornoj komunikaciji upotrebljavaju diskurs koji nam je dobro poznat iz tadašnje likovne kritike. „Formulaični način izlaganja, sklonost stalnom iznošenju definicija, neprestano ista objašnjenja i identične ocjene (...) odraz su nastojanja likovne kritike da ostvari neku vrstu jezične 'monosemije', potpune terminološke jasnoće, jasnoće posve adekvatne društvenoj stvarnosti." ${ }^{13}$ Riječ je o didaktičnom diskursu, prepunome praktičnih naputaka, ${ }^{14} \mathrm{u}$ kojemu dominiraju binarne opozicije-niz pozitivnih sintagmi kao značajki socijalističkoga društva i estetike, u suprotnosti s kojima stoje negativne oznake kao obilježja umjetnosti Zapada, poput formalizma, bezidejnosti, dekadencije, egzistencijalizma. ${ }^{15}$

Nakon Rezolucije Informbiroa (dalje: IB) u rano ljeto I948. ULUH službeno osuđuje Rezoluciju na plenarnom sastanku već 9 . srpnja I948. i potvrđuje da umjetnici čvrsto stoje uz CKKPJ i obvezuju se da će „otvoriti jasan put socijalističkom realizmu i stvaranju istinskih djela iz NOB-a i socijalističke izgradnje zemlje". ${ }^{16}$ Međutim, situacija se u ULUH-u zaoštrava: neki uvaženi članovi iz redova uprave ULUH-a uhvaćeni su u propitkivanju službenoga stava KPJ u vezi s IB-om zbog čega su kažnjeni. ${ }^{17}$ ULUH u svojim izvještajima i pismima u poslijeinformbiroovskom razdoblju (I949-- I95I.) pooštrava retoriku po pitanju ideološkoga rada, inzistira na sistematskoj političko-ideološkoj aktivnosti, sve kako bi se podigla politička svijest članstva, a ULUH postao važna snaga u izgradnji socijalizma. Ovdje vrijedi obratiti pozornost na činjenicu da nakon IB-a $u$ ULUH-u nije došlo do očekivanoga popuštanja ideološke stege, već naprotiv, ona doživljava svoj vrhunac u razdoblju nakon I948. godine. To zapravo nije neobično jer je socijalistički realizam kanoniziran, „kao ostalim oblicima izražavanja nadređena (državna) umetnost, tek na V. kongresu KPJ, I948. godine, neposredno posle sukoba sa sssR i Rezolucije IB-a”, a „u tom trenutku, još postoji nada da će se odnosi sa SSSR poboljšati”. ${ }^{18}$ „Govorom Milovana Đilasa na v. kongresu KPJ, socrealizam je, dakle, dobio svoj puni partijsko-definisani zamah."19

Iz izvještaja ULUH-ovih skupština i plenuma iz I949., I950., I95I. i I952. godine vidljiva je ozbiljna stega na ideološkom području u tome razdoblju: organiziraju se predavanja i diskusije, planski se nabavlja literatura za političko-ideološki rad i „idejnu izgradnju članstva" kako bi mogli sudjelovati u diskusijama, predviđa se da će izložbeni salon ULUH-a služiti izlaganju najuspjelijih djela socijalističkog realizma, članovi se potiču za odlazak na javna radilišta u svrhu stvaranja likovnih dokumenata o „radnom poletu naših naroda”, a na zidnim novinama izvješena je zbirka fotografija s radnih akcija kako bi se članovi mogli orijentirati u izboru tema za svoje radove. ${ }^{20}$ Nadalje, Društvo priprema „članke o estetici od Rozentala i Pavlova u 25o primjeraka”, koji su uglavnom rasprodani među članovima, svake treće nedjelje u mjesecu Agitprop CK organizira predavanja za likovne umjetnike, književnike i muzičare (likovni umjetnici su najbrojniji, no prigovara se članovima ULUH-a da ne sudjeluju u diskusijama jer ne uče i zato bojažljivo pristupaju diskusijama, zbog čega trebaju ovladati naukom stvaranju optičke realnosti do kolorističkog šarenila palete i sjajno jednolične površine itd." sonJA BRISKI UZELAC (bilj. I), 60.

I2 „Možda u slici i nije toliko presudan temat, koliko sadržaj, t.j. duh, da se tako izrazim, ili ideja koja nosi sliku (...) sadržaj je ono što s jedne strane daje tematu iskrenost, a s druge strane formalne elemente stapa, apsorbira u nov adekvatan izraz (...) Naš sadržaj je naš današnji napor, naša ljubav prema boljem životu, naša mržnja prema svemu što ponizuje čovjeka, naša egzaltacija rada i žrtve-kao jedinog mogućeg sredstva, da prijeđemo iz predhistorije u historiju". PETAR ŠEGEDIN, Povodom Treće izložbe likovnih umjetnika Hrvatske, u: Naprijed, 52 (I947.), 5 .

I3 LJILJANA KOLEŠNIK (bilj. I), 32 .

I4 U čemu diskurs kao da doslovno slijedi naputke iz jednog od Agitpropovih dokumenata: „U ocjenjivanju kulturno-umjetničkog djelovanja treba se držati sasvim širokog mjerila. Ne smije se dozvoliti jedino nikakav revizionizam u teoretskom pogledu na tom polju i pojave dekadense treba odlučno suzbijati. Inače svaki rad na kulturno-umjetničkom polju što dobronamjernije prihvatiti, ali ga ujedno u našoj štampi kritički ocjenjivati i davati upute za poboljšanje toga rada". Izvještaj i prijedlozi za rad Agit-propa, koji su diskutovani sa drugom Djilasom, vjerojatno iz I945., HDA, fond CK SKHI220, Agitprop I945.- I954., kut. I.

I5 Više o hrvatskoj socrealističkoj likovnoj kritici u: ANA ŠEPAROVIĆ, Desirable and Stigmatized: Subject, Form and Content as the Main Categories in the Croatian Socialist Realist Art Criticism Discourse (1945-ı950), u: IKON, II (2018.), I67-I78.

I6 Tajnički izvještaj, 27. veljače I949., HDA, fond HDLU I979-2, kut. 25 .

I7 U vezi s tim formirana je komisija (Krsto Hegedušić, Vanja Radauš, Vilko Šeferov, Marijan Detoni, Kavurić) koja vrši ispitivanje „sumnjivih” članova (Velibor Mačukatin, Ante Despot, Đuro Tiljak, Grga Antunac i Petar Franjić). Franjić, Despot i Mačukatin su uhapšeni, a Tiljak i Antunac maknuti s rukovodećih mjesta u Društvu. Izvještaj komisije za ispitivanje slučaja Tiljak/Antunac, 20. siječnja I950., HDA, fond HDLU I979-2, kut. 25 .

I8 Lidija Merenik to potkrepljuje riječima iz referata Josipa Broza Tita s istog kongresa u kojem stoji: „Ja bih podvukao da će naša Partija i naš Centralni komitet raditi svim silama da se odnosi između naše Partije i $\operatorname{SKP}(b)$ opet poprave. Mi se nadamo da će drugovi rukovodioci $\operatorname{SKP}(\mathrm{b})$ dati nama mogućnosti da mi ovdje, na licu mjesta, dokažemo sve što je netačno u rezoluciji." LIDIJA MERENIK, Umetnost i vlast, Beograd, 20ıо., 26.

I9 LIDIJA MERENIK (bilj. I7), 26-27.

20 Prema:Zaključci glavne godišnje skupštine iz veljače I949., Tajnički izvještaj, 27. veljače i949. i Odgovor SLUJ-u, bez nadnevka, sve u: HDA, fond HDLU I979-2, kut. 25 . 
marksizma-lenjinizma), članstvo se poziva na političko informiranje (navodi se da odaziv nije velik), a tijekom I95I. sektor za ideološko-politički rad organizira predavanja Grge Gamulina, Rudija Supeka i Ervina Šinka. ${ }^{21}$ Iako je moguće da je pritisak u vezi s idejno-političkim radom na ULUH od strane Agitpropa i Saveza likovnih umjetnika Jugoslavije (dalje: SLUJ) $\mathrm{u}$ tom postinformbiroovskom razdoblju bio snažniji zbog pojave struje koja podupire Informbiro (tzv. "grupašenje”) unutar sama vrha Društva, ${ }^{22}$ jačanje „konzervativnih” težnji u razdoblju između r948. i I95I. može se uvjerljivije objasniti pokušajem konsolidiranja nakon velikog potresa, gdje ideologija postaje utočište nakon poljuljanih odnosa s glavnim saveznikom. Društvo se okreće čvrstim ideološkim temeljima, inzistira na snažnom idejno-političkom jedinstvu kako bi se stabiliziralo; takva politika traje nekoliko godina, dok god je živa „drama” oko Informbiroa.

Oko I95o. na širem društveno-političkom polju započinje tzv. dekonstrukcija socrealizma i proces ponovne kanonizacije modernizma, a u kontekstu kreditno-monetarnog okretanja Jugoslavije prema Zapadu (I95I). Govorom Edvarda Kardelja u Ljubljani potkraj r949. Partija objavljuje namjeru povlačenja iz područja duhovnih djelatnosti, ${ }^{23}$ kulturna se javnost otvara informacijama iz kulturnih centara zapadnih zemalja, a Jugoslavija sudjeluje na venecijanskome Bijenalu ı95o. godine. Sve je zastupljenije zagovaranje slobode i individualnosti u umjetnosti, osobito uočljivo na važnim izlaganjima poput Šegedinova referata na Drugom kongresu Saveza književnika Jugoslavije krajem I949. godine. ${ }^{24}$ i Krležinih govora na Drugom i Trećem Kongresu Saveza književnika Jugoslavije I950. i r952. godine. ${ }^{25}$ Govor Miroslava Krleže r952. u Ljubljani simbolički je označio kraj razdoblja socrealizma u nas, a u sljedećim godinama socrealistička doktrina zamijenjena je ideologijom visokog modernizma, čime će se i ULUH naći na sasvim novim pozicijama.

U djelovanju ULUH-a prijelaz iz socrealističke u modernističku paradigmu najavilo je i simbolički označilo izlaganje Krste Hegedušića na godišnjoj skupštini ULUH-a u veljači I950., ${ }^{26}$ kada on upravnom odboru Društva predlaže sasvim nove zadatke: podupiranje osnivanja likovnih grupa, poticanje rasprava i borbe suprotstavljenih mišljenja na sastancima unutar Društva, ali i s članovima Društva hrvatskih književnika te pokretanje časopisa u kojem svaki član može slobodno surađivati. ${ }^{27}$ Sve navedeno jasno upućuje na svijest o potrebi redefiniranja uloge ULUH-a u likovnom životu Hrvatske unutar sasvim nove umjetničke ideologije modernizma.
2I Izvještaj sektora za idejno-politički rad, iz I950. i Referat predsjednika V. Šeferova, veljača I950., HDA, fond HDLU I979-2, kut. 25; Izvještaj godišnje skupštine, I952.; Izvještaj sektora za idejno-politički rad, I95I., HDA, fond HDLU I979-2, kut. 26.

22 Zapravo kod Tiljka i Antunca nije bilo riječi o pravoj potpori IB-u već više o oklijevanju i kolebljivosti u trenutačnoj i jednoznačnoj osudi IB-a.

23 Prema: LJILJANA KOLEŠNIK (bilj. I), 68

24 PETAR ŠEGEDIN, O našoj kritici, u: Republika, I (I95o.), $3-\mathrm{I} 2$.

25 MIRoslav KRLEŽA, Riječ u diskusiji na Drugom kongresu književnika Jugoslavije, u: Republika, I (I950.), I3-I7; MIROSLAV KRLEŽA, Govor na kongresu književnika u Ljubljani, u: Republika, Io/II (I952.), $205-243$

26 KRSTO HEGEDUŠIĆ, Riječ o kritici i organizaciji kritike, u: Republika, 2/3 (I95о.), IIо-II6.

27 Važnost ovoga izlaganja istaknula je i argumentirala Ljiljana Kolešnik. LJILJANA KOLEŠNIK (bilj. I), 73-77. 
Tekst je nastao kao dio istraživanja provedenih u okviru projekta I5o godina Hruatskog društua likounih umjetnika (20I6.-20I8.), koja su u konačnom obliku objavljena u poglavlju monografije. Usp. ANA ŠEPAROVIĆ, U znaku totalitarizama, u: I5o godina Hrvatskog društva likounih umjetnika: umjetnost $i$ institucija I868-20I8, (ur.) Irena Kraševac, Zagreb, 20I8., I73-200; ANA ŠEPAROVIĆ, ULUH oko Informbiroa: dinamika ideološko-političkoga pritiska u likovnome stvaralaštvu, u: Peristil, 60 (2017.), I03-II6.

Autorica je na 4. kongresu hrvatskih povjesničara umjetnosti izlagala pod naslovom Udruženje likounih umjetnika Hrvatske u kontekstu socrealizma u sklopu panela I5o godina djelovanja Hrvatskog društva likovnih umjetnika na kojem su sudjelovali: Tamara Bjažić Klarin, Tomislav Buntak, Iva Matija Bitanga, Dalibor Jelavić, Irena Kraševac, Ivana Mance, Ana Šeparović, Robert Šimrak, Petra Šlosel i Josip Zanki.

\section{(ㄷ) (i)}

Mehanizmi kontrole i usmjeravanja likovne produkcije: ULUH u kontekstu socrealizma / Ana Šeparović / CC BY / 4.0

DoI: https://doi.org/10.31664/z4khpu.36 